\title{
Heritage Tourism and Its Impact on The Local Communities: A Case Study in Ranau, Sabah
}

Nurulhuda Mohamad Yusof, Er, A.C, Ummuliyana Halim, Nurul Misha Hanysha Halimin, Mohd Zulfahmi Othman, Noordeyana Tambi \& Nurul Fadilah Mohd. Nawi

To Link this Article: http://dx.doi.org/10.6007/IJARBSS/v11-i12/8260 ～DOI:10.6007/IJARBSS/v11-i12/8260

Received: 06 October 2021, Revised: 09 November 2021, Accepted: 26 November 2021

Published Online: 22 December 2021

In-Text Citation: (Yusof et al., 2021)

To Cite this Article: Yusof, N. M., A.C, E., Halim, U., Halimin, N. M. H., Othman, M. Z., Tambi, N., \& Nawi, N. F. M. (2021). Heritage Tourism and Its Impact on The Local Communities: A Case Study in Ranau, Sabah. International Journal of Academic Research in Business and Social Sciences, 11(12), 1805 - 1830.

Copyright: @ 2021 The Author(s)

Published by Human Resource Management Academic Research Society (www.hrmars.com) This article is published under the Creative Commons Attribution (CC BY 4.0) license. Anyone may reproduce, distribute, translate and create derivative works of this article (for both commercial and non0-commercial purposes), subject to full attribution to the original publication and authors. The full terms of this license may be seen at: http://creativecommons.org/licences/by/4.0/legalcode

Vol. 11, No. 12, 2021, Pg. $1805-1830$

Full Terms \& Conditions of access and use can be found at http://hrmars.com/index.php/pages/detail/publication-ethics 


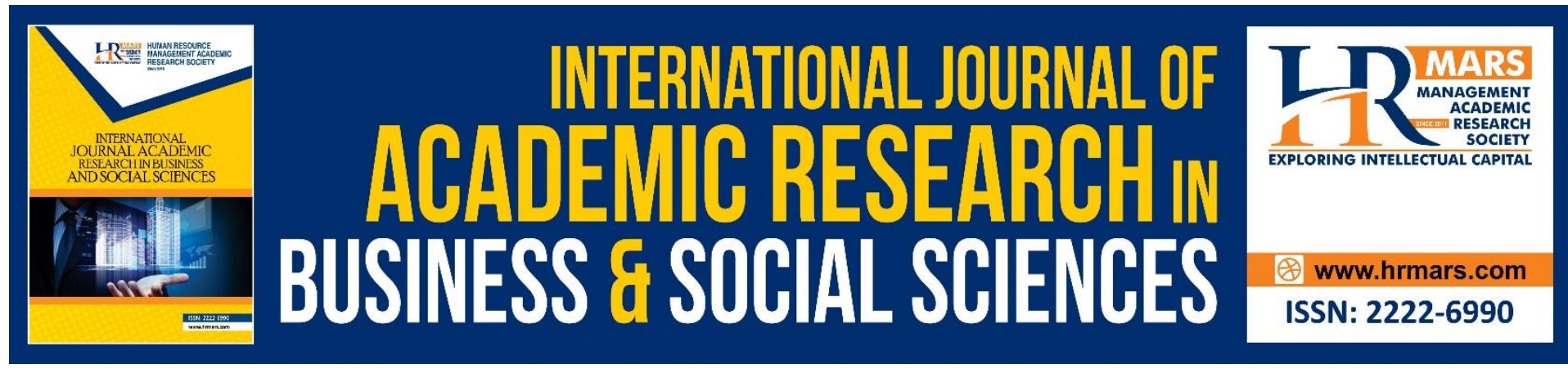

\title{
Heritage Tourism and Its Impact on The Local Communities: A Case Study in Ranau, Sabah
}

\section{Nurulhuda Mohamad Yusof ${ }^{1}$, Er, A.C ${ }^{2}$, Ummuliyana Halim¹, Nurul Misha Hanysha Halimin ${ }^{1}$, Mohd Zulfahmi Othman ${ }^{1}$, Noordeyana Tambi ${ }^{2} \&$ Nurul Fadilah Mohd. Nawi ${ }^{3}$}

${ }^{1}$ Developmental Science Programme, Faculty of Social Sciences and Humanities, Universiti Kebangsaan Malaysia, 43600, Bangi, Selangor Darul Ehsan, Malaysia, ${ }^{2}$ Center for Research in Development, Social and Environment (SEEDS), Faculty of Social Sciences and Humanities,

Universiti Kebangsaan Malaysia, 43600, Bangi, Selangor Darul Ehsan, Malaysia,

${ }^{3}$ Environmental Management Programme, Faculty of Social Sciences and Humanities,

Universiti Kebangsaan Malaysia, 43600, Bangi, Selangor Darul Ehsan, Malaysia.

Corresponding Author Email: eveer@ukm.edu.my

\begin{abstract}
This research discusses the six (6) elements of tourism destinations and their impacts on local communities in Ranau, Sabah. The elements are attractions, accessibility, amenities, available packages, activities and ancillary services. A total of 200 respondents were involved in this survey based on a set of questionnaires. The results indicated that there are six elements of tourism destination in the study area and the most prominent element is the attraction element as it potentially enhances awareness on the conservation of the cultural and social heritage among the local community. The results of this research are beneficial to all stakeholders, especially the Government, tourism-related industry, the hospitality industry, and the local community to improve the performance of the elements at the destination. Overall, the existence of tourism destination elements in a tourism area provides satisfaction to tourists and encourages return visits and provides assistance to local communities such as raising income, quality of life and cultivating the spirit of cooperation and self-esteem towards the future development of heritage tourism destinations.
\end{abstract}

Keywords: Destination Elements, Heritage Tourism, Repeat Tourist, Impact.

\section{Introduction}

The tourism industry has expanded rapidly into one industry that helps to improve the economic growth and development of a country (Muhammad et al., 2016). According to Mondal \& Sen (2017), the tourism sector has become a very important sector by rapidly increasing its contribution to the Gross Domestic Product value (GDP) to the country that offered it. This industry is also an intelligent investment that can drive the growth of other related industries. Globally, the tourism industry is important as it can develop the physical, social, cultural, economic, political and technological aspects at the same time become the source of income to a country (Hausman, 2001). Based on the World Tourism Organization 
(WTO) record, the tourism aspect has become an important global economic sector since the mid-1990s and several earliest countries have benefited significantly from tourism namely, Portugal, Brazil, Spain, Tunisia and many others (Wan et al., 2015). The WTO also stated that the tourism industry could be seen as the main contributor to economic recovery due to its ability in producing millions of employment opportunities (Muhammad et al., 2016).

Malaysia is no exception in joining the global tourism sector in the developing country category. This proves that the tourism sector is vital to the country's growth. According to Mohd Uzir (2018), the tourism sector recorded a 14.9 per cent \% contribution towards the growth of the Malaysian economy in 2017 compared to $10.4 \%$ in 2005. This shows a pattern of growth since the year 2005 and is growing rapidly with an average annual growth rate of $11.2 \%$ over the last 12 years. The direct contribution of the tourism industry to GDP recorded 6.1\% with a value of RM 82.6 billion in 2017 compared to RM76.6 billion in 2016, an increase of RM6 billion. This mainly reflects the economic activities generated by industries such as hotels, travel agencies, airlines and other passenger transportation. The direct contribution of travel and tourism to GDP is expected to experience a growth of $5.2 \%$ per annum to RM100.4 billion (5.4\% of GDP) by 2027 . This indirectly proves that the tourism sector not only helps to increase and expand the sources of income of the country but also to introduce Malaysia closer and nearer to the world.

The WTO also stated that tourism growth has brought important responsibilities to the operators, government and individual tourists towards the local community (Sanna, 2012). This was supported by Johan et al (2012) who states that a location becomes a tourist attraction due to the uniqueness of the tourism resources available. The massive tourists' arrivals have successfully increased the popularity of a destination which led to the active involvement of the Government in formulating policies, planning the infrastructure and land use, and attracting private sector involvement in providing quality facilities and services and promoting the involvement of the locals in tourism thus improving their socio-economic status. However, despite the rapid development of a destination, tourism can have both positive and negative effects on the environment (Johan et al., 2012). The negative effects should be well controlled to not threaten its future development. Unstructured planning and ad hoc development will result in widespread pollution and utilisation of the tourism resources to be prevalent and unsustainable for the future generation. Besides, the unorderly development poses other issues such as fire, safety, pollution, criminal acts, sensitivity and others which will ultimately create an unconducive atmosphere among tourists and the locals.

Tourism has various dimensions and the definition of tourism can be defined in a variety of ways. The WTO defines tourism as a social, cultural and economic phenomenon that involves the movement of individuals or human groups into countries and places outside the common environment for personal, business or professional purposes (Sanna, 2012). According to $\operatorname{Er}$ (2013), tourism refers to the activity of visiting, tour or travelling to a place more than 50 miles from the residence for a short period for recreational or leisure purposes. The tourism typicology types were divided into five (5) categories namely, ethnic tourism, cultural tourism, historical tourism, environmental tourism and recreational tourism (Valene, 1979). Cultural tourism refers to tourism activities that made cultural elements a major attraction including performance, lifestyle, cultural heritage, architecture and all elements that characterized the community's way of life in a destination (Mohamed, 2008). Meanwhile, Aissa and Abd Al Khuja (2014) stated that there are various types of tourism in Malaysia including ecotourism, agro-tourism, ethnic tourism, beach tourism, and heritage tourism. Heritage tourism is a combination of natural and cultural heritage. 
Currently, heritage has become increasingly important to tourists (Mohammad et al., 2008). In most parts of the world, heritage is categorized as one of the main components of tourism development especially when it is combined with tourism and recreational activities. It is noted that travel activities on heritage-based destinations have evolved rapidly. In the global context, most of the world's main tourist attractions are heritage cities listed as the World Heritage including cities such as (i) Paris in France; (ii) York, Bath, Cambridge and Oxford in England; (iii) Amsterdam in 'Netherland; and (iv) Pisa, Venice, and Florence in Italy. These cities are well-known to tourists around the world. Malaysia has many heritage cities that can be preserved and several have been listed as world heritage and have the potential to become tourist attractions such as Georgetown, Malacca, Kuching, Kota Bharu and Taiping (Mohamad et al., 2008). Therefore, conservation and preservation efforts of historical heritage are important as they can serve as tourism products and assets to a country. This is because if the preservation of heritage is planned, heritage treasures can be sustained, preserved and well restored, it can eventually be shown to the next generation (Siti \& Zuliskandar, 2018).

With the uniqueness of its existing heritage, Malaysia can attract more domestic and foreign visitors to boost the tourism sector. There is no exception to the state of Sabah which is very well known for its highland tourism area in Kundasang with the background of Mount Kinabalu. Kundasang is a settlement area in the Ranau district, the central part of Sabah. It is located in the Crocker range area which has a height of around 4,000 feet to 6,000 feet. The area has several major villages, including the Permai Valley, Cinta Mata, Kauluan, Sinisian, Dumpiring and Kinasaraban (Ramzah \& Amriah, 2008). The Kinabalu National Park is located in Kundasang and it has been recognized as the World Heritage Park by UNESCO since the year 2000. The preservation of heritage treasures is important and should be prioritised by various levels of society especially the local communities. These heritage elements have their uniqueness and historical values which are distinctive and non-replaceable. However, in the face of the rapid development of the heritage tourism sector, there are some tendencies of neglect and decline in the management of tangible or non-tangible cultural assets, especially in rural areas. Poor level of management of the assets and understanding of cultural diversity seems to be lacking in the assessment of the elements of tourism destinations in locations with cultural heritage assets, especially for the national-scale cultural assets. The problem arises from a lack of concern for the state of affairs of existing cultural heritage assets (Volare, 2012).

The study by Ramzah and Amriah (2008) concludes that the tourism industry has yet become an effective catalyst to the development of Kundasang due to the influence of three factors, namely: (i) the sluggish growth of the urban centre concerning the failure of Kundasang town to be developed as an effective urbanization centre; (ii) income leakage due to the arrival of the migrant community who has swept the opportunities and wealth of the natural resources neglecting the indigenous community; and (iii) the low self-esteem of the local people due to poor ability to face the impact of development activities implemented. The current scenario in Ranau and its surrounding areas particularly in Ranau shows that there are various elements of tourism destinations that have existed in the areas of tourist attractions. However, unplanned development could destroy the heritage site in the study area and the destruction could reduce the number of heritage sites. This is because there are notable natural heritage and cultural destinations such as Kinabalu National Park and Poring Hot Spring that need to be preserved and made as heritage treasures for future generations. The study was conducted to identify the elements of tourism destinations which exist in the 
heritage tourist attraction area in Ranau, Sabah and reviewing the impact of its activities on the local community. In this regard, the views of the tourists who visited the tourism areas around Ranau will also be taken into consideration apart from the locals in the village and Ranau town that have been identified to be analysed in this study. The population of this study was made up of people who lived in Ranau, Sabah while the sample of this study consists of tourists who have visited and carried out tourism activities at the heritage tourism locations in Ranau, Sabah including the locals around the village and Ranau, a small town in Sabah that has been identified as the research area.

\section{Literature Review \\ Heritage Tourism}

Heritage tourism refers to the activities closely related to the culture, tradition, old legacy, and also the community's way of life offered as a product in the tourism market (Mohamed \& Zulayti, 2011). Heritage tourism is also seen as a tendency, involvement, activity undertaken, and experience gained by tourists in a destination that offers heritage products. Heritage tourism is one of the attractions for the tourist to visit an area. The difference in heritage and culture among tourists has prompted the desire to know more about the local heritage and culture either by observation or experience. Heritage tourism can be regarded as a person's encouragement to heritage attractions, whether it is a 'high' or 'low' attraction to gain knowledge and experience of life. Heritage tourism is one of the main attractions in the development of tourism products (Habibah et al., 2011). The heritage tourism products in Malaysia include the multi-racial life, street culture, Chinatowns, Little India, rural living in paddy fields and fishermen, local food stalls, weddings and festivities (Mohamed \& Zulyati, 2011). In addition, the attraction of heritage tourism products has attracted tourists to visit Malaysia because heritage tourism has its own unique and distinctive attractions. Heritage tourism can be highlighted through the tangible and non-tangible cultural context in various aspects of tourism offered by states located in the East Coast Regional Economic Corridor (ECER). Pahang, Kelantan and Terengganu are well-known areas rich in local heritage products that are still resilient and very well known to international and domestic tourists. Furthermore, Malacca is the tourism area of the UNESCO World Heritage Site. Most of the tourists have chosen Malacca as a family holiday destination because there are various national heritage treasures and historical sites in the state (Er, 2013). The conservation of heritage resources will be enhanced as a result of the appreciation and experience of tourists who experience and appreciate their heritage tourism (Moscardo, 1996; Ramkissoon, 2015). This scenario has influenced most European countries to develop their historical heritage including artefacts of old buildings or old cities and to relate to important historical events, maintaining and rebuilding the historical locations in their country. The re-use of historical materials and the revitalization of historical memory for tourism activities can protect important resources and help preserve the uniqueness of a community in an area (Neumayer, 2004). Cultural heritage requires that people maintain their cultural form which was practised since the past. Current modernity had brought changes to the community, it has gradually shifted its position towards a more advanced life, indirectly leaving behind the cultural practices that were considered to be no longer relevant (Thiele et al., 2005).

\section{Heritage Tourism in Sabah}

The presence of local and international tourists in Sabah is for various purposes. A variety of tourism destinations available in Sabah such as sea products shopping, highlands and 
mountains or historical heritage sites have made it a popular attraction for tourists to the state. Hence, various initiatives have been implemented by the Sabah State Government and Ministry of Tourism, Arts and culture in enhancing the diversity of historical heritage products and the upgrading of infrastructure for the convenience of tourists and the local communities. The strong cooperation between the State and the Federal Government is expected to further enhance the tourism activities that can further promote heritage tourism in Sabah as an option as a tourism destination both locally and internationally. The Sabah State Government is targeting a total of 4 million tourist arrivals in 2019 compared to 3.8 million in 2018. Consequently, a wide range of ongoing promotions is implemented including the introduction of the "Sabah the Best of Borneo" slogan to illustrate a variety of tours offered to tourists namely, natural heritage and community culture themed tourism (Sabah Tourism Board, 2019). The diverse background of Sabah's multiracial population, ethnicity and culture has made Sabah one of the distinguished tourism destinations in the Asian region. For the state of Sabah, the main attractions which attract tourists both domestically and abroad are the natural resources, culture and heritage of its ethnic community. The prominent image often featured for Sabah's tourism are mountains, islands, marine life, forest and wildlife, ethnic community's culture and the combination of these images (Rosmalina, 2012).

The Kinabalu National Park has been recognized by UNESCO as a Natural Heritage Park due to its mega ecology with diverse habitat from tropical rainforest areas, tropical mountain forest areas, semi-alpine forests and tall shrubs. It has been classified as the Southeast Asian Plants Diversity Centre and is very rich in examples of flora from the Himalayas, China, Australia, and Malaysia including universal Tropical plants (UNESCO, 2019). Sabah's heritage and cultural tourism activity have grown rapidly. Besides products related to nature and cultural heritage, products based on historical and artificial heritage such as Sinsuran Grand Market, Kundasang War Memorial, Poring Hot Spring, Ranau Paragliding Park and Sabah Tea Plantation are also offered. Comfortable five to two-star accommodation, quality food courts and souvenir shops were also built. However, the development of tourism activities will certainly affect the quality of the environment and the destruction of the environment. At present, the concept of sustainable tourism development has begun to be practised to ensure not only the environment but other resources including historical and cultural heritage in Sabah are preserved. The issue of preserving tourism activities in Sabah has always been challenging as most of the tourists to the state stay for a short period and are temporary. Therefore, they are less sensitive to the desire of preserving the beauty and together maintain the uniqueness of natural resources and culture at the destination that they visited. A study conducted by Loon (2018) has identified the level of sustainability of cultural tourism in Sabah which found that there are weaknesses in efforts to maintain the sustainability of cultural tourism in the state. This scenario will certainly affect the presence of returning tourists to the state. Hence, in ensuring that the heritage tourism activity in a tourism destination can be successfully implemented, the application of the elements of tourism destinations is very important. This is because the elements of a tourism destination will be the key factor that attracts and highlights the uniqueness of existing heritage tourism products and further increased the number of domestic and international tourists to Sabah every year.

\section{Diversity of Heritage Tourism Elements}

Buhalis (2000) in his research states that there are six elements in tourism activities or 'Six A's Framework for Analysis Tourism Destination' which include (1) attractions, (2) accessibility, 
(3) amenities, (4) tour package (available packages), (5) tourism activities (activities) and (6) ancillary services as in Table 1.

Table 1. Tourism destination element

\begin{tabular}{|l|l|}
\hline \multicolumn{1}{|c|}{ Element } & \multicolumn{1}{c|}{ Description } \\
\hline Attractions & $\begin{array}{l}\text { Nature, heritage, culture, man-made, ceremonies or } \\
\text { special events. }\end{array}$ \\
\hline Accessibility & Connectivity system-roads and transportation. \\
\hline Amenities & Accommodation, retails and food facilities. \\
\hline $\begin{array}{l}\text { Tour package } \\
\text { (Available packages) }\end{array}$ & $\begin{array}{l}\text { All activities are done by tourists such as hiking, looking at } \\
\text { the scenery, dancing, fishing, and others. }\end{array}$ \\
\hline Ancillary services & $\begin{array}{l}\text { Services to be used by tourists such as banks, hospitals, } \\
\text { postal, and money changers. }\end{array}$ \\
\hline
\end{tabular}

Source: Buhalis (2000)

\section{i) Attraction Element}

The success of a heritage tourism destination depends on the offering of something unique and different from other tourism destinations (Godfrey \& Clarke, 2000). A location that serves as a tourism destination will be seen from the uniqueness or specialities at the destination to be a tourist attraction. It is also stated by Basri (2013) that the tourist attractions can be categorized according to their physical characteristics, either permanent, temporary or mobile. Permanent attraction means a tourist attraction that has a permanent site and physical features such as a historical building or nature.

\section{ii) Accessibility Element}

The accessibility element is to link the tourists' original accommodation to the tourism destination that will be visited by road, sea or air (Ahmad et al., 2013). The type of accessibility often used by tourists for tourism activities is air transportation, marine transportation and land transportation.

\section{iii) Amenity Element}

The amenities provided at the tourism destination is an important element to determine the success of a tourism destination (Ritchie \& Crouch, 2003, pp.95). According to Ahmad et al. (2013), every tourism destination should be concerned about each amenity provided and should take into account its importance to the community as a consumer. The quality of service provided has to be high and friendly to the tourists and it is the main element in the concept of a tourism destination. Cooper et al. (2004) has stated that a tourism destination is a destination with specific infrastructures and amenities to meet the needs of the tourists. The infrastructures and amenities provided will facilitate tourism activities during the trip. Infrastructure and amenities must be provided with the cooperation of the Government and stakeholders to further develop the area and help the local community to provide the best services to the visiting tourists.

\section{iv) Tour Package Element}

Tourists who are interested in historical heritage are individuals interested in finding a natural or 'authentic' experience (Mohd \& Sulong, 2013). Therefore, there is a need for each authority and the stakeholders to provide materials or tour packages that can attract tourists. If it 
relates to historical visits, then they need to find the authenticity of the inheritance materials that can be remembered through their experience. Thus, in western countries such as Britain, France and Italy, the tourism management and local Government will endeavour and work together to multiply the tour packages which promote the historical heritage so that it can be enjoyed by the visitors. In Iran, destination factors became important factors when a person chose a tourism destination. Iran can become a cheap tourism destination with high currency rates that have been able to attract tourists from foreign countries (Hamid \& Mohammad, 2015).

\section{v) Tourism Activities Element}

The heritage and cultural tourism activities in Malacca have been growing rapidly (Er, 2013). Besides products related to historical and cultural heritage, products based on natural sources such as beaches, fishing in the sea, Lipor forests, Water Theme Park, Malacca Zoo, Butterfly Farm and Mini Park Malaysia are also offered. There are international level hotels, food courts and restaurants built for tourists' choice. However, the rapid growth of tourism activities does not guarantee its level of sustainability. The large and diverse supply of tourism products and services can adversely affect the quality of the environment and the destruction of natural resources. The concept of heritage tourism development is now adopted and practised to ensure that not only the environment but other resources including historical and cultural heritage within the city of Malacca are always preserved.

\section{vi) Ancillary Amenities Element}

Research conducted by Mohamad et al (2013) has studied the level of visitors' satisfaction visitors with the services and facilities at the Kilim Karst Geoforest Park (KKGP), Langkawi. The results of their study found that the level of visitors' satisfaction with the services and facilities at the KKGP were low. Therefore, based on the results obtained by the researchers, an action plan was proposed by the researcher to improve the services and facilities at the KKGP especially in the management, planning and services section to be implemented in a planned manner and its performance to be periodically and regularly monitored.

\section{The Impact of Heritage Tourism}

The development of the heritage tourism industry in an area or destination that has the potential to be developed is highly encouraged as the tourism industry has proven to contribute to a variety of positive impacts, especially to the local communities. The positive impact not only involves the socio-economic aspects but also includes the socio-cultural and environmental aspects of the local community. Tourism development takes into account the economic, social and cultural factors of the local communities and environment as the determinant of development. These factors have a chain effect on each other. If the tourism development only emphasises the economic factors without regard to the impact on the environment, the development undertaken is not sustainable (Ko \& Stewart, 2002; Kuvan \& Will, 2005; Shukor et al., 2014).

\section{i) Economy}

Tourism has led to economic growth and an increase in revenue thus making tourism the most important sector and proves that the existing level of development will attract more tourists and economic development (Seetanah, 2010). Tourism activities can create new employment, improve the quality of infrastructure (roads, water, electricity and public 
transport), enhance the social phenomena among the locals, and tourism development have made the community aware that they need to be involved and participate in tourism management to generate income (Candra, 2014). Also, tourism development creates employment opportunities and increases the income of the local community (Jurowski et al., 1997). Through these employment opportunities, the local community can generate their income and thus improve their standard of living.

\section{ii) Social}

The social impact involves the relationship between individuals and other individuals or with the community and how the individual communicates among them. The study on community relations was conducted to see the changes which occurred before and after the tourism industry in the area was steadily developing (Suhaya et al., 2013). Broader and more social impact elements not only involving the relationship between family and community but also in the association, social demands between the Government and the people and the integration of one community with another community (Scoones, 1998). Tourism could change the social condition of both the local communities and the tourists. In some countries with seasonal tourism such as Greece and Turkey, the locals will be staying in different places. They will be staying at the tourist attraction areas to work in the summer and return home when the winter arrives. This scenario has changed and influenced the community's lifestyle in terms of their location of residence which differ according to the specific season (Melanie, 2015).

\section{iii) Environment}

The Okavango Delta is one of the leading areas of heritage tourism in Bostwana due to its rich wildlife resources and a beautiful and picturesque tourism area (Joseph, 2003). The tourism activity which took place in Okavango Delta was booming after being developed as a tourism destination. The study found that despite the positive socio-economic impact of tourism on the standard of living of the local community, the tourism activities had negatively impacted the environment. Examples include ecological destruction, sound pollution and poor solid waste management in the Delta region. This is evident when there are piles of rubbish such as plastic bags, paper and bottles along the way and at the Okavango Delta campsites. In this regard, it can be attributed to the sustaining ability of an area for a certain period. This explains the state of 'sustaining ability' where tourism activities will result in negative changes or damage to the environment and thus change the pattern of tourism experience in an area (Jamaluddin, 2009). Therefore, every study of the environmental impact and tourism development should take consider the important role of sustaining ability which will influence the relationship between tourist arrivals and the sustaining ability of the physical environment of a tourism area.

The results of previous studies on the impact of tourism generally showed different effects on each community whether they are positive or negative or both. It was found that the local community will support the development of heritage tourism and be involved in tourism activities if the community received high benefits from the costs which they have incurred. However, if the community requires higher costs than the benefit received, they will reject the development of heritage tourism as it will negatively impact the quality of life. The conceptual framework was formed using the tourism destination elements used by Buhalis (2000) and previous researchers to help the researchers understand the existing elements of 
a tourism destination that influenced the tourists to visit the heritage tourism destination in Ranau, Sabah as shown in Figure 1 below.

Figure 1. Research conceptual framework

\begin{tabular}{|c|c|c|c|c|c|}
\hline \multicolumn{6}{|c|}{ TOURISM DESTINATION ELEMENTS } \\
\hline Attraction & Accessibility & Amenities & $\begin{array}{l}\text { Available } \\
\text { packages }\end{array}$ & $\begin{array}{l}\text { Tourism } \\
\text { Activities }\end{array}$ & $\begin{array}{l}\text { Ancillary } \\
\text { Services }\end{array}$ \\
\hline $\begin{array}{l}\text { - } \quad \text { Natur } \\
\text { al. } \\
\text { - Man- } \\
\text { made. }\end{array}$ & $\begin{array}{l}\text { - Transportati } \\
\text { on service. } \\
\text { - Road } \\
\text { network. }\end{array}$ & $\begin{array}{ll}\text { - } & \text { Basic } \\
\text { Ameniti } \\
\text { es. } \\
\text { - Ancillary } \\
\text { Ameniti } \\
\text { es. }\end{array}$ & $\begin{array}{ll}\text { - } & \text { Tour } \\
\text { package } \\
\text { quality. } \\
\text { - } \\
\text { Local } \\
\text { people } \\
\text { engageme } \\
\text { nt in tour } \\
\text { packages. }\end{array}$ & $\begin{array}{ll}\text { - } & \text { Type of } \\
\text { tourism } \\
\text { activities. } \\
\text { - } \quad \text { Local } \\
\text { people } \\
\text { engagem } \\
\text { nt in } \\
\text { tourism } \\
\text { activities. }\end{array}$ & $\begin{array}{l}\text { - The } \\
\text { clinic, } \\
\text { touris } \\
\mathrm{m} \\
\text { centre, } \\
\text { House } \\
\text { of } \\
\text { Worshi } \\
\text { p, } \\
\text { Securit } \\
\text { y } \\
\text { Service } \\
\text {. } \\
\text { Ancillar } \\
\text { y: Car } \\
\text { rental, } \\
\text { ATM, } \\
\text { post } \\
\text { office. }\end{array}$ \\
\hline \multicolumn{6}{|c|}{ IMPACT OF TOURISM ON THL_OCAL COMMUNITY } \\
\hline \multicolumn{2}{|c|}{ Economy } & \multicolumn{2}{|c|}{\begin{tabular}{|c|} 
Social \\
\end{tabular}} & \multicolumn{2}{|c|}{ Environment } \\
\hline $\begin{array}{c}\text { Living } \\
\text { standards }\end{array}$ & $\begin{array}{c}\text { Tourism } \\
\text { development }\end{array}$ & $\begin{array}{c}\text { Cultural } \\
\text { heritage } \\
\text { conservati } \\
\text { on }\end{array}$ & $\begin{array}{l}\text { Community's } \\
\text { quality of life }\end{array}$ & $\begin{array}{c}\text { Environment } \\
\text { al } \\
\text { conservation }\end{array}$ & $\begin{array}{c}\text { Level of } \\
\text { awareness }\end{array}$ \\
\hline $\begin{array}{l}\text { - Employ } \\
\text { ment } \\
\text { Opportunitie } \\
\text { s } \\
\text { - Increase } \\
\text { in } \\
\text { commun } \\
\text { ity's } \\
\text { income. } \\
\text { - The } \\
\text { occurren } \\
\text { ce of } \\
\text { foreign }\end{array}$ & $\begin{array}{l}\text { - The high } \\
\text { cost of } \\
\text { living; } \\
\text { - Increase } \\
\text { in } \\
\text { infrastruc } \\
\text { ture cost; } \\
\text { - Increase } \\
\text { in } \\
\text { tourism } \\
\text { tax. }\end{array}$ & $\begin{array}{l}\text { - } \text { Cultura } \\
\text { I } \\
\text { heritag } \\
\text { e is } \\
\text { protect } \\
\text { ed; } \\
\text { - Cross- } \\
\text { cultura } \\
\text { I } \\
\text { exchan } \\
\text { ges } \\
\text { occur; } \\
\text { Existen } \\
\text { ce of }\end{array}$ & $\begin{array}{l}\text { - Increased } \\
\text { education } \\
\text { al } \\
\text { opportuni } \\
\text { ties; } \\
\text { - The } \\
\text { safety } \\
\text { aspect is } \\
\text { given } \\
\text { attention; } \\
\text { Crime } \\
\text { rate and } \\
\text { social } \\
\text { problem }\end{array}$ & $\begin{array}{l}\text { - Natural } \\
\text { conserva } \\
\text { tion is } \\
\text { maintain } \\
\text { ed; } \\
\text { The } \\
\text { quality } \\
\text { of nature } \\
\text { is } \\
\text { protecte } \\
\text { d; } \\
\text { Nature } \\
\text { attractio } \\
\mathrm{n} \text { is }\end{array}$ & $\begin{array}{l}\text { - Water and } \\
\text { air } \\
\text { pollution } \\
\text { are } \\
\text { reduced; } \\
\text { - Waste } \\
\text { disposal is } \\
\text { controlled } \\
\text {; } \\
\text { Increase } \\
\text { in } \\
\text { environm } \\
\text { ental } \\
\text { protection }\end{array}$ \\
\hline
\end{tabular}




\begin{tabular}{|c|c|c|c|c|}
\hline $\begin{array}{l}\text { exchang } \\
\text { e. } \\
\text { Improve } \\
\text { d living } \\
\text { standard } \\
\text { s. }\end{array}$ & $\begin{array}{l}\text { cross- } \\
\text { culture } \\
\text {; } \\
\text { - Cultura } \\
\text { I } \\
\text { values } \\
\text { are } \\
\text { upheld } \\
\text {. }\end{array}$ & $\begin{array}{l}\text { are } \\
\text { controlled } \\
\text {; } \\
\text { The } \\
\text { quality of } \\
\text { life of the } \\
\text { people is } \\
\text { improved. }\end{array}$ & $\begin{array}{l}\text { increase } \\
\text { d. }\end{array}$ & awareness \\
\hline
\end{tabular}

Source: Adapted from Buhalis (2000) and Inskep (2001)

\section{Method}

This is a case study conducted at several heritage tourism sites, villages and small towns located within the district of Ranau, Sabah. The study areas involved are Kilimu village, Ranau town, Poring Hot Spring, Kundasang and Kota Kinabalu, Sabah. The areas were selected as study areas because it is the locations of most of the popular tourist destinations in Sabah such as Kinabalu National Park, Desa Cattle Dairy Farm, Sabah Tea Plantation and Poring Hot Spring and the Desa Lestari village, a successful sustainable village in Sabah. Figure 2 shows the full map of the Ranau district in Sabah.

Figure 2. Map showing Ranau district in Sabah

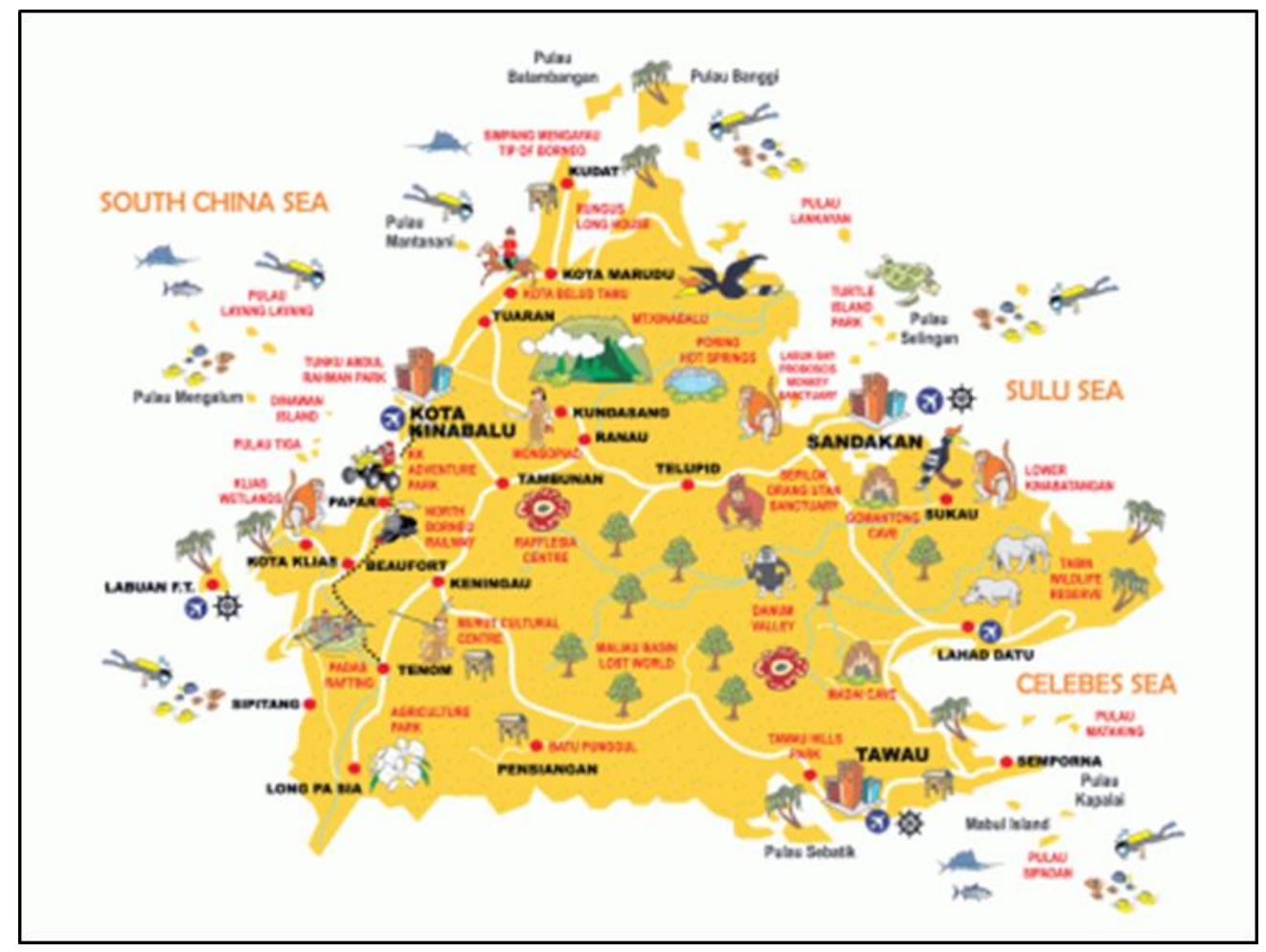

Source: Greenhill (2019)

This study uses the mixed method which is a combination of quantitative and qualitative methods. The data used are primary data and secondary data. Primary data is the data collected from the field using questionnaires that were distributed to the respondents. This 
primary data is seen to provide a clearer picture of the actual situation in the study area (Barbie, 2009). The secondary data was used to provide additional information concerning issues studied and examples of secondary data used are information obtained from brochures, newspapers and information from the Internet. This study uses the nonprobability sampling method with sample selection made on a simple sampling (convenient sampling). Through this method, individuals were chosen to be likely incidentally or chosen because the individual is believed to be able to provide the necessary information. Therefore, not everyone has the same opportunity to be chosen as a sample. The sample size is 200 people targeting the sample features of tourists and locals based on the target number of respondents according to tourist location as shown in Table 2.

Table 2. Target breakdown and achievement of the number of respondents by study area

\begin{tabular}{|l|c|c|c|c|}
\hline No. & Name of Place & Research date & $\begin{array}{c}\text { Number of } \\
\text { targeted } \\
\text { respondents }\end{array}$ & $\begin{array}{c}\text { The number of } \\
\text { respondents for the } \\
\text { questionnaire } \\
\text { obtained }\end{array}$ \\
\hline 1. & $\begin{array}{c}\text { Kilimu Village, } \\
\text { Ranau }\end{array}$ & $18-19$ Mac 2019 & 100 & 56 \\
\hline 2. & Ranau Town & $18-19$ Mac 2019 & 25 & 74 \\
\hline 3. & $\begin{array}{c}\text { Poring Hot } \\
\text { Spring }\end{array}$ & 19 Mac 2019 & 25 & 38 \\
\hline 4. & Kundasang & 20 Mac 2019 & 25 & 11 \\
\hline 5. & Kota Kinabalu & 20 Mac 2019 & 25 & 21 \\
\hline \multicolumn{2}{|c|}{ Total Number of Respondents Involved } & 200 Respondents & 200 Respondents \\
\hline
\end{tabular}

Questionnaires were used as an instrument or tool to gather information and data in this study. The questionnaire was handed over to the respondents in the study area to be filled by the respondent and to be returned to the research team. The composition of the questionnaire form is divided into five sections; a) Tourism activities available in your area, b) elements of tourism destinations, c) level of engagement in tourism, d) impact of tourism on the local community, and e) recommendations and improvements. This instrument uses the four points Likert Scale of 1-Strongly Disagree, 2-Disagree, 3-Agree and 4-Strongly Agree.

All data collected through questionnaires were analysed using SPSS software. The analysis of this study includes descriptive analysis in the form of frequency, percentage and mean value and factoring method, and the inferential analysis of correlation test. This is to facilitate the researchers' teams to provide an assessment on the elements of tourism destinations in the study area besides identifying whether there is a significant relationship between the elements and impacts involved in this study. The factor analysis method was also used in the analysis of this study. This method is used to classify the statements in the questionnaire into several themes. An Gie \& Pearce (2013) stated that the factor analysis method is often used to compile variables into several small groups. This is because factor analysis can focus on key factors or themes alone without considering too many variables at a time (Rummel, 1970, para. 617). The use of factor analysis in this study helps facilitate the correlation analysis and avoid the correlation between the statements of similar meaning. Hence, the data can be analysed more clearly and easier to understand. The classification of statements found in the elements of a tourism destination is as shown in Table 4. 
Table 4. Classification of statements in element by theme

\begin{tabular}{|c|c|c|}
\hline $\begin{array}{c}\text { Tourism } \\
\text { Destination } \\
\text { Element }\end{array}$ & Theme & Statement \\
\hline \multirow{7}{*}{ Attraction } & \multirow{5}{*}{ Nature } & The environment has a natural element \\
\hline & & Physically, the area is still green \\
\hline & & The air in the area is clean and refreshing \\
\hline & & No extensive land exploration \\
\hline & & There are biological and habitat diversity \\
\hline & \multirow{2}{*}{ Culture } & Interesting cultural attraction \\
\hline & & There is a heritage uniqueness \\
\hline \multirow{6}{*}{ Accessibility } & \multirow[b]{2}{*}{ Road network } & Access to public transport \\
\hline & & $\begin{array}{l}\text { The safe and comfortable public } \\
\text { transportation system }\end{array}$ \\
\hline & \multirow{4}{*}{$\begin{array}{c}\text { Public } \\
\text { transportation } \\
\text { service }\end{array}$} & $\begin{array}{l}\text { The exit and entrance path are smooth } \\
\text { and orderly }\end{array}$ \\
\hline & & Roads are in good condition \\
\hline & & Road accidents decrease over time \\
\hline & & Good road conditions save travel time \\
\hline \multirow{7}{*}{ Amenities } & \multirow{4}{*}{ Basic amenities } & $\begin{array}{l}\text { There are plenty of accommodations } \\
\text { available }\end{array}$ \\
\hline & & $\begin{array}{l}\text { There are many dining outlets such as } \\
\text { stalls and restaurants }\end{array}$ \\
\hline & & $\begin{array}{l}\text { Primary schools and Secondary Schools } \\
\text { are located nearby }\end{array}$ \\
\hline & & Many public toilets are available \\
\hline & \multirow{3}{*}{$\begin{array}{l}\text { Ancillary } \\
\text { amenities }\end{array}$} & There are many retail businesses \\
\hline & & There are many petrol stations \\
\hline & & Car park areas are plenty and safe \\
\hline \multirow{6}{*}{ Tour package } & \multirow{4}{*}{$\begin{array}{l}\text { Tour package } \\
\text { quality }\end{array}$} & $\begin{array}{l}\text { Many tourism activity packages are } \\
\text { offered }\end{array}$ \\
\hline & & Package prices are very affordable \\
\hline & & $\begin{array}{l}\text { Tour package services offered are the } \\
\text { best }\end{array}$ \\
\hline & & Budget travel packages are offered \\
\hline & \multirow{2}{*}{$\begin{array}{l}\text { The locals' } \\
\text { engagement in } \\
\text { tour packages }\end{array}$} & $\begin{array}{l}\text { Tour packages are supported by } \\
\text { stakeholders }\end{array}$ \\
\hline & & $\begin{array}{l}\text { The local community are involved in } \\
\text { providing tour packages }\end{array}$ \\
\hline \multirow{3}{*}{ Tourism Activities } & \multirow{3}{*}{$\begin{array}{l}\text { Type of tourism } \\
\text { activities }\end{array}$} & $\begin{array}{l}\text { A wide selection of tourist and leisure } \\
\text { activities is offered }\end{array}$ \\
\hline & & $\begin{array}{l}\text { Heritage tourism activities are suitable for } \\
\text { the whole family }\end{array}$ \\
\hline & & The tourism activities offered are safe \\
\hline
\end{tabular}


INTERNATIONAL JOURNAL OF ACADEMIC RESEARCH IN BUSINESS AND SOCIAL SCIENCES Vol. 11, No. 12, 2021, E-ISSN: 2222-6990 @ 2021 HRMARS

\begin{tabular}{|c|c|c|}
\hline $\begin{array}{c}\text { Tourism } \\
\text { Destination } \\
\text { Element }\end{array}$ & Theme & Statement \\
\hline & & $\begin{array}{l}\text { Tourism activities that care for the } \\
\text { disabled and children }\end{array}$ \\
\hline & $\begin{array}{l}\text { Local } \\
\text { community }\end{array}$ & $\begin{array}{l}\text { Tourism activities generate income for the } \\
\text { local community }\end{array}$ \\
\hline & $\begin{array}{l}\text { engagement in } \\
\text { tourism }\end{array}$ & $\begin{array}{l}\text { Tourism activities are assisted by } \\
\text { community leaders and activists }\end{array}$ \\
\hline & activities & Tourism activities are very profitable \\
\hline \multirow{8}{*}{ Ancillary services } & \multirow{5}{*}{ Basic } & Banks and ATMs are available \\
\hline & & $\begin{array}{l}\text { Clinics and health centres are located } \\
\text { nearby }\end{array}$ \\
\hline & & $\begin{array}{l}\text { Tourist service centre/counter are } \\
\text { available }\end{array}$ \\
\hline & & $\begin{array}{l}\text { Security services are provided for risky } \\
\text { activities }\end{array}$ \\
\hline & & Places of worship facilities are available \\
\hline & \multirow{3}{*}{ Ancillary } & The post office is available \\
\hline & & $\begin{array}{l}\text { Foreign currency exchange facilities are } \\
\text { easily available }\end{array}$ \\
\hline & & $\begin{array}{l}\text { Motorcycle/bicycle for the rental is } \\
\text { available }\end{array}$ \\
\hline
\end{tabular}

The statement classification found in the tourism impact section is shown in Table 5. Elements that have been classified into several themes were then analysed together with the impact of tourism using the Spearman Rho correlation analysis to see the relationship which exists between the two. 
Table 5. Statement classification in elements by theme

\begin{tabular}{|c|c|c|}
\hline $\begin{array}{c}\text { Tourism impact on } \\
\text { the local } \\
\text { community }\end{array}$ & Theme & Statement \\
\hline \multirow{6}{*}{ Economy } & \multirow{4}{*}{ Standard of living } & Increase in employment opportunities \\
\hline & & Increase in household income \\
\hline & & Increase in prices of goods \\
\hline & & $\begin{array}{l}\text { Increase in the standard of living and } \\
\text { socio-economic of the community }\end{array}$ \\
\hline & \multirow{2}{*}{$\begin{array}{c}\text { Tourism } \\
\text { development }\end{array}$} & $\begin{array}{l}\text { Increase in Government's revenue from } \\
\text { tourism taxes }\end{array}$ \\
\hline & & $\begin{array}{l}\text { Enhancement of infrastructure } \\
\text { development }\end{array}$ \\
\hline \multirow{7}{*}{ Social } & \multirow{3}{*}{$\begin{array}{l}\text { Cultural Heritage } \\
\text { conservation }\end{array}$} & $\begin{array}{l}\text { Conservation of cultural heritage is } \\
\text { protected }\end{array}$ \\
\hline & & Cultural values uphold \\
\hline & & There is an existence of cross-culture \\
\hline & \multirow{4}{*}{$\begin{array}{l}\text { Society quality of } \\
\text { life's }\end{array}$} & $\begin{array}{l}\text { The community's standard of living is } \\
\text { improved }\end{array}$ \\
\hline & & Increased in educational opportunities \\
\hline & & The safety aspect is given attention \\
\hline & & $\begin{array}{l}\text { Crime rate and social problems are } \\
\text { controlled. }\end{array}$ \\
\hline \multirow{6}{*}{ Environment } & \multirow{4}{*}{$\begin{array}{l}\text { Environmental } \\
\text { conservation }\end{array}$} & $\begin{array}{l}\text { Conservation of the natural and man- } \\
\text { made environment is maintained }\end{array}$ \\
\hline & & $\begin{array}{l}\text { Environmental quality level is } \\
\text { maintained }\end{array}$ \\
\hline & & Nature attractiveness increases \\
\hline & & $\begin{array}{l}\text { Environmental care sensitivity } \\
\text { increases }\end{array}$ \\
\hline & \multirow{2}{*}{$\begin{array}{l}\text { The communities' } \\
\text { level of awareness }\end{array}$} & $\begin{array}{l}\text { Reduce the water, air and sound } \\
\text { pollution }\end{array}$ \\
\hline & & $\begin{array}{l}\text { The waste disposal problem is } \\
\text { controlled }\end{array}$ \\
\hline
\end{tabular}

\section{Findings}

\section{Profile of Respondents}

This study was conducted on 200 respondents, comprising of 160 local respondents and 40 international respondents. Based on Table 6, most of the respondents are females at 110 people or $55 \%$. This is because the study was conducted on working days with most of the male population (head of the family) has left for work early in the morning. The majority of the respondents are 20-29 years of age, 60 people (30\%). In terms of racial distribution, the highest number of respondents was other ethnics groups, 158 people at 79\%, and classified as Sabah's Bumiputera. Of the total, 102 people, $51 \%$ of other ethnic respondents comprised of the Dusun ethnic. This is in line with the Statistical data of the community profile in the Ranau district which is the majority of the Kadazan/Dusun (Sabah State Statistics Department, 
2014). Other ethnic groups involved are Bajau, Brunei, Bugis, Iban, Kedayan, Murut, Sino, Rivers, Timor and international tourists (no ethnicity). For the respondents' employment sector, the majority worked in other sectors (self-employed, farmers, unemployed, housewives, retirees), representing 66 respondents (33\%). This is in line with the Ranau district population profile data issued by the Ranau District office where the majority of the residents are involved in agricultural activities (farmers and paddy farmers) and operating their businesses. For the gross monthly income, the majority of the respondents had a low income of between RM501 to RM1, 000 per month which is 58 people (29\%). For the duration of stay, a total of 105 people (53\%) of the respondents showed that the majority had lived there for more than 16 years.

\section{Elements of Tourism Destinations that Exist in the Study Area}

Figure 3 shows the elements of tourism destinations that exist in the study area namely attraction, accessibility, amenity, tourism activities, tour packages and ancillary services. From Figure 3, the mean value of each tourism destination element in the study area can be seen where the attraction element obtained the highest mean value of 3.3814 compared to other elements. This shows that the attraction element is the most significant in the study area.

Figure 3. Types of tourism destination elements

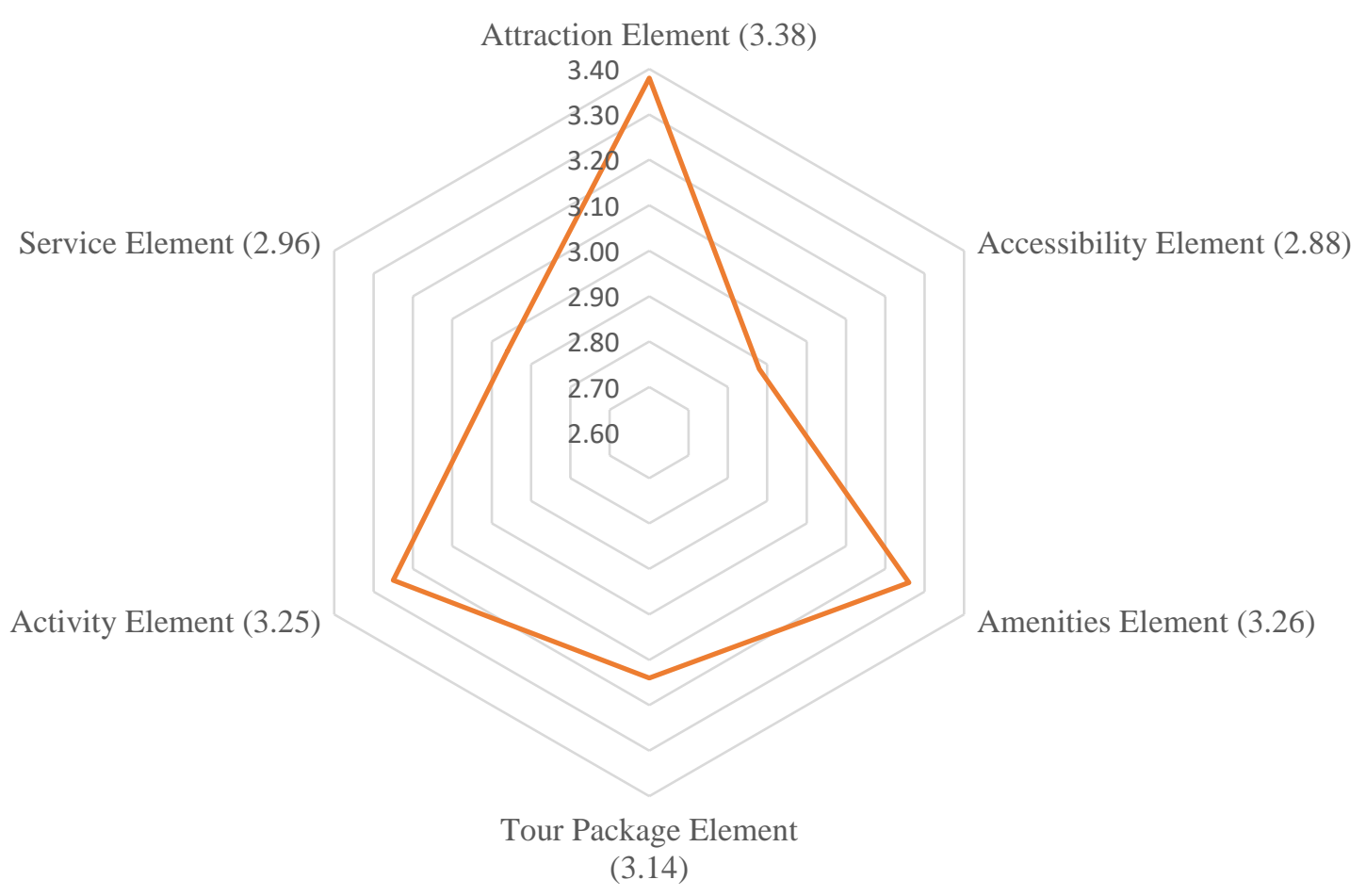

Based on Figure 3, the attraction element is seen as the most significant element of the heritage tourism area in Ranau when compared to other elements. The element of attraction is one of the must-have elements in the tourism area. Tourism areas should have attractions such as infrastructure and attractive places to become popular tourist destinations (Basri, 2013). The study on the elements of tourism destinations in Ranau showed that the dominant attraction elements are related to natural and social elements. Referring to Figure 3, the 
element that looks significant after the attraction element is the amenity element. The mean value of this element is 3.2686 . This element focuses on infrastructure and amenities which exist in an area. The presence of this element in the tourism area is important to help the local community provide the best services to the tourists. This is because tourists will usually avoid visiting a tourism destination that does not have an infrastructure or offering poor infrastructure (Basri, 2013). Besides, the presence of this element in the tourism area has benefitted the local community as the development of the tourism industry will enable them to use better amenities compared to areas that are not involved in tourism activities (Suhaya et al., 2013).

The mean value for the tourist activity element is 3.2583 . This element provides a hint of tourism activities in a tourism area. Exciting and diverse tourism activities will provide more employment opportunities for the local community especially those suitable for their interest and creativity, for example, paragliding, fishing and climbing activities which will attract tourists and influence the development of the existing tourism industry. For tour package element is 3.1417. Although the tour package element is seen as less prominent in the study area, this element is important in a tourism area as it is seen to influence the existence of many local companies competing to offer the best and affordable tour packages to tourists. Tourists interested in historical heritage are keen to find a genuine or 'authentic' experience (Mohd \& Sulong, 2013). Next is the ancillary service elements. With a mean value of 2.9613, this element is considered a complementary element in tourism. The existence of this element can have a positive impact on the quality of life of the local community. This is because services such as facilities for worship, automated teller machines (ATM), post offices and clinics are essential services needed by the community in the development of an area, especially in a heritage tourism destination. Lastly is the element of accessibility. Referring to Figure 3 , it can be seen that the accessibility element has a mean value of 2.8886 . Although the element was less prominent in the study area, the existence of the accessibility element helped to facilitate the locals. The availability of transportation roads such as roads, highways, and bridges will facilitate the transportation of goods from an area to another will boost the economy of the people in the area (Abdul, 2006).

\section{Tourist Destination Element and Heritage Tourism Impact Correlation}

Correlation analysis between tourism destination elements (attractions, accessibility, amenities, tour packages, tourism activities and ancillary services) with heritage tourism impact (economic, social and environmental) was conducted using Spearman's Rho Correlation Method. Based on Figure 5, the result of correlation analysis shows varying coefficient levels. The coefficient strength levels can be categorised as follows:

Table 6. Correlation Strength Levels

\begin{tabular}{|c|c|}
\hline \multicolumn{2}{|c|}{ Coefficient Level } \\
\hline $0.10-0.29$ & Low \\
\hline $0.30-0.49$ & Moderate \\
\hline $0.50-1.0$ & High \\
\hline
\end{tabular}

To see the relationship of elements and heritage tourism impact with more depth, the correlation analysis was divided into three parts namely economic, social and environmental. The correlation results between tourism destination elements and tourism impact like in Figure 4. 
Figure 4. The relationship between tourism destination elements and tourism impacts

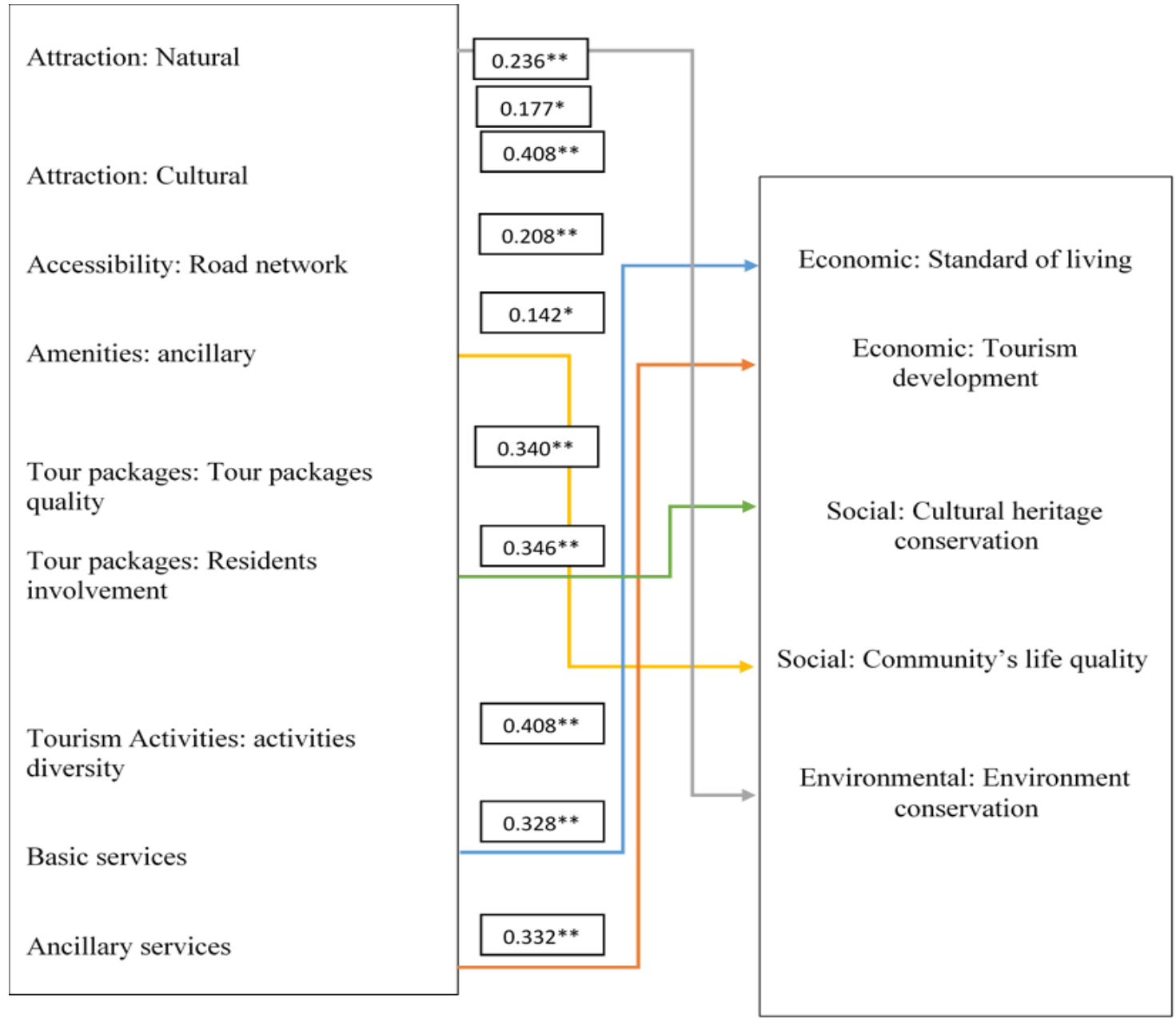

\section{Economy}

\section{i) Local Standard of Living}

The correlation between elements and impacts of heritage tourism having the highest correlation value from an economic aspect is the product of tourism activity correlation: activity diversity at the heritage tourism area and economic impact: locals' standard of living. Based on Figure 4, coefficient value, $r=0.408^{* *}$ shows that there is a moderate positive relationship between the element and impact that have been correlated. This proves the existence of a connection between the tourism activity element and economic impact. This can be seen through economic activities that are run by the residents of Kilimu village either individually or communally through Kilimu Jaya Ranau Public Cooperative. The cooperative runs accommodation packages through chalets and homestays as well as tourism activity packages in Ranau. One of the activity packages offered is sightseeing around Kundasang using cooperative owned vans besides Kadazan Dusun ethnic cultural activities. Besides, in Kilimu Village cabin premises are also built and are rented by small village businesses to sell food and beverage as well as locally made handicraft products. Through these economic activities, the standard of living and the socioeconomic level of the residents can be increased. This indirectly increases the household income besides increasing new employment opportunities offers to be filled by the locals. If seen from the tourism element package, the quality of tour packages offered also gives effect to the economic aspect. Referring to Figure 5 , coefficient value, $r=0.340^{* *}$ proves the existence of a significant relationship between 
economic impact and the element of tour package quality. Quality tour packages in an area are considered to give an effect on tourists' emotions and consequently influence the arrival of returning tourists. The involvement of local residents in tour packages has indirectly helped to reduce the unemployment rate. Milman and Pizam (1988) state that tourism activities give direct and indirect impacts on job opportunities and entrepreneurship. Ross (1992) also supports this matter by stating that an increase in job opportunities is one of the positive impacts of tourism in a particular area.

Next, it is related to the basic services elements such as clinics/health centres, tourism service counters, and the house of worship amenities. These elements were categorised as service elements that must be available in a tourism area. It can be seen from Figure 4 that the basic services element also has a positive and significant relationship with the economic aspect that is residents' standard of living with a coefficient value, $r=0.328^{* *}$. The presence of these elements is expected to be able to give an impact on the economy by attracting more tourists. In the study area, the elements of the basic service existed and are believed to be able to affect tourist arrivals. The majority of respondents also agreed that the ancillary services element such as clinics, tourism service counters, banks and ATMs, and post offices are available and located nearby the study area. The emphasised is on the importance of supporting amenities such as information technology, clean public toilets, foreign currency exchange amenities, transit amenities, safes, as well as other amenities for the needs of domestic tourists, family tourists and explorers in tourist zones (Hanizah et al., 2017).

The natural attraction element is seen to less affect the economic aspect. Referring to Figure 4, the correlation result shows a coefficient value, $r=0.177^{*}$ that is still significant but is a considerably low value if compared to other coefficient values. This shows that this element is less affecting the economic aspect. It is probably because local residents in the study area were less involved in nature-based tourism activities. In Ranau, there is habitat and biological diversity and physical areas that are still green and still have great potential to be a tourist attraction area. This is in line with Inskeep (1991) who states that the environment is a resource for tourism. In general, natural environment resources are the main attraction for tourists. Tourists will be attracted to areas with scenic views, refreshing climate, white beaches, clear seawater and natural environments and landscapes that are attractive and beautiful (Habibullah, 1999). However, based on observation, it is found that not many local residents tend to involve themselves in jobs related to the natural attraction element as a source of income. For example, at Poring Hot Spring, one of the tourist attraction areas based on nature, the number of local residents who participate in tourism activities are limited because the management of the area is conducted by the state government and tourism companies from outside the area bring in tourists into the area. The factors of belief, religion, economic and traditional factors are the cause of the lack of full involvement of locals in the cultural tourism sector in Sabah, although government policy also provides support and assistance to these efforts (Siow et al., 2014).

\section{ii) Tourism Development}

Next is concerning the economic impact on tourism development. The correlation result that is done between the impact and ancillary services element shows a coefficient value of $r=$ $0.332^{* *}$ which is moderate but significant and has a positive relationship. Ancillary services element consists of services like banks and ATMs, post offices, foreign currency exchange services, and car and motorcycle rentals. The respondents who were interviewed in the study area have the opinion that tourism development in the study area has affected the 
infrastructure development in the heritage tourism area in Ranau. This is due to the yearly increasing number of tourist arrivals that has prompted many ancillary infrastructures to be added in Ranau. Services like ATMs for example can be found in a lot of areas especially in tourist attraction areas in Pekan Ranau, Pekan Telipok, and Kota Kinabalu.

\section{Social}

\section{i) Cultural Heritage Conservation}

The elements which exist in heritage tourism destinations also give an impact on the social aspect of Ranau. Correlation analysis was done and a coefficient value of $r=0.408^{* *}$ proves that there is a relationship between the cultural attraction element and social impact. For example, the cultural attraction element that exists in the study area has helped to conserve the available cultural heritage. In Kilimu Village, many cultural attractions are featured such as cultural dance, as well as traditional delicacies and beverages. According to Godfrey and Clarke (2000), the success of a heritage tourism destination depends on the offering of something unique and different from other tourism destinations. This matter can be seen with the tourism sector in Ranau that offers numerous tourism activities with the concept of cultural heritage uniqueness. Besides, the element of tour packages also helps in ensuring cultural heritage in the study area to be preserved. This matter can be seen from the coefficient value of $r=0.346^{* *}$ which is moderate and proves a positive relationship. The locals who are involved in tour packages have helped to introduce tourists to the cultural heritage that is in the tourism area. For example, in Kilimu Village, many locals involved themselves in an offering of tour packages. The involvement of locals includes the form of providing homestay packages and tour guides.

\section{ii) Community's Life Quality}

The correlation that was done among the accessibility element: road network and social impact: the community's life quality shows that there is a moderate relationship which is $r=$ $0.208^{* *}$. Roads with good conditions that save travelling time can help residents to move from one area to another area with ease. However, a few respondents suggested that the existing roads be upgraded because perforated and narrow road conditions will make it difficult for residents and endangering tourists to use them. Road accidents will also increase if poor road conditions are not handled promptly. Next is the correlation for amenities element: ancillary and social impact: the community's life quality. The coefficient value that shows the relationship for this element and impact is low but significant which is $r=0.142^{*}$. Ancillary amenities like many retail businesses located in a tourism area and gas stations located nearby are elements that help to increase the life quality of the community in the study area. This has eased the locals and tourists because they do not need to go far to get daily necessities and goods. Residents can generate their economy by being involved in retail businesses. For example, In Kilimu Village, several retail stores are run by the locals.

\section{Environment}

\section{i) Environmental Conservation}

The environmental aspect is an important aspect of the tourism sector because it is one of the aspects that can promote Ranau as a heritage tourism area. Based on Figure 4, the correlation value that is done between attraction element; natural and impact; environmental conservation is observed to have a coefficient value of $r=0.236^{* *}$. In this study, the natural attraction element is seen to affect the environment in terms of 
environmental conservation even though the coefficient value is low, yet it is still significant. The presence of tourists to see the beauty of natural attractions in a tourism area has specially made locals more aware of cleanliness and the beauty of tourism areas so that they will not be polluted. Based on the researcher's observation, among the areas that often become a tourist hotspot in Ranau like Kinabalu National Park, Poring Hot Spring and Desa Cattle Dairy Farm generally looked clean and preserved.

Besides, there are signage or signboards made by the area's management that prohibit visitors to litter or vandalise. This shows that there are cooperation and concern from the local community to maintain the cleanliness and beauty of the environment in the area. Other than that, the researcher was also offered by the residents of Kilimu Village to participate in the Hampuan Hill hiking activity which is located not far from the village to see the Rafflesia flower growing on that hill. This flower is very popular because it is the official flower for the state of Sabah. It shows that locals are more aware of natural resources conservation and it has enabled the promotion of tour packages in their area by making Rafflesia flower as one of the natural attractions and consequently inculcating love for the environment in the local community. However, this environmental conservation has to be a continuous activity as stated by Johan et al (2012) that most of a nation's main attractions are related to natural attractions and heritage elements that are not replenishable, so the efforts of taking care and conserving those resources are much needed and it should be implemented continuously.

\section{Conclusion}

The objective of this study is to identify the six elements of tourism destinations, namely elements of attractions, accessibility, amenities, available packages, activities and ancillary services. Also, this study analyses the impacts of six elements on local communities in Ranau,

Sabah. This research results show that there are destination elements namely, accessibility, amenities, tour packages, tourism activities element and also ancillary services element in Ranau. This is because Ranau needs certain elements that are not only able to attract tourists, but also to meet the needs and wants of the local community. The existence of destination elements in Ranau has given positive impacts in terms of economic, social and also environmental. The local community is satisfied with the impact received through heritage tourism activities that occurred in Ranau. The most considerable impact to the local community is the economy, followed by social and environmental. The impact of heritage tourism development in the economic aspect shows that there is an increase in the community's standard of living as a result of the involvement of the local community in providing tour packages and the expansion of many ancillary amenities such as car rental services, ATM amenities and post offices. From the social aspect, tourism development increases the community's quality of life and education opportunities like the ability of residents to communicate in a foreign language (English) with tourists, it indirectly gives exposure and interpersonal skills to the local community. From the environmental aspect, the development of Ranau as a heritage tourism destination has led to an increase in the community's image and awareness towards environmental conservation like at Kinabalu Mountain and Poring Hot Spring. Thus, the encouragement of environmental conservation through pollution prevention and control programmes and enhancing environmental quality has to be enhanced.

It is hoped that this study can contribute to the government, industry and the local community in understanding the functions of tourism destination elements that exist in line 
with their roles and their effects on the tourism industry. As mentioned by Loon (2018), to address the problems and challenges faced in the heritage tourism industry, comprehensive cooperation between the government, cultural village operators, tourist guides, and local communities to achieve sustainable development is needed. Thus, to keep stimulating the involvement of the local community, the government has to study the improvements that can be executed such as intensifying education and training programmes to potential residents and residents who are interested in heritage tourism activities. This matter is needed to ensure that the management skills and knowledge are obtained by the community and subsequently allowing them to be able to become useful information distribution agents to tourists. Besides, the basic amenities element that gives importance to the security aspect and periodical maintenance to be frequently stressed by the authorities. It is needed to promptly handle road safety issues like potholes and landslides since Ranau's terrain and geographical conditions are hilly and of high altitude poses a high risk. The industry needs to ensure employment opportunities and economic activities based on heritage tourism be prioritised for the local community rather than foreign workers. It is to avoid migration to the city and an increase in unemployment, especially among local youths.

The local community need to be more proactive and ready to accept modern elements and the development implemented in their village life without neglecting traditional and cultural practices that become the basis of the local cultural uniqueness. This scenario is to ensure the involvement and strong commitment received from all groups of the community and this continuous commitment will surely bring benefit to their future. This study model can be expanded by evaluating the feedback or tourism destination elements impact towards tourists particularly after they returned from the destination like their desire to revisit the destination, dissipating information about the destination, and recommending the destination to acquaintances and family. Besides, dynamic destination elements like the scenario or current situation at the destination such as political condition, types of products and services offered have to be taken into consideration in evaluating the result of this tourist visitation in the future.

\section{Acknowledgement}

The authors would like to express their heartfelt gratitude to Universiti Kebangsaan Malaysia (UKM) under research grant IDE-2018-006 and TAP-K007351 lead by Professor Dr. Er Ah Choy for the funding this research.

\section{Reference}

Abdul, K. (2006). Transportasi: Peranan dan dampaknya dalam pertumbuhan ekonomi nasional. Jurnal Perencanaan \& Pengembangan Wilayah. Wahana Hijau 1(3), 121-131. https://www.academia.edu/9198472/TRANSPORTASI_PERAN_DAN_DAMPAKNYA_DA LAM_PERTUMBUHAN_EKONOMI_NASIONAL.

Aissa, M., \& Abd Al Khuja, M. S. (2014). A Review of Tourism Development in Malaysia. European Journal of Business and Management, 6(5), 1-9. https://citeseerx.ist.psu.edu/viewdoc/download?doi=10.1.1.735.8292\&rep=rep1\&typ e=pdf.

Ahmad, N. A. A., Habibah, A., Hamzah, J., Mohd Yusof, H., Amriah, B., \& Winarni, S. (2013). Pembentukan konsep destinasi mesra pelancong: Konsep berorientasikan pelancong sebagai pengguna. Esteem Academic Journal, 9(2), 16-27. https://ir.uitm.edu.my/id/eprint/8905. 
Gie, Y. A., \& Pearce, S. (2013). A Beginner's Guide to Factor Analysis: Focusing on Exploratory Factor Analysis. Tutorials In Quantitative Methods For Psychology 9(2), 79-94. https://doi.org/10.20982/TQMP.09.2.P079.

Barbie, E. (2009). The Basics of Social Research (5th ed). Chapman University.

Basri, R. (2013). Elemen destinasi dan kesan terhadap pengalaman percutian. Geografia Malaysian Journal of Society and Space 9, Issue 4 (118-127). http://journalarticle.ukm.my/6659/1/12ok.geografia-okt2013-basri-edkat.pdf .

Buhalis, D. (2000). Marketing the competitive destination of the future. Tourism Management, 21, 97-116. https://doi.org/10.1016/S0261-5177(99)00095-3.

Cooper, C., Fletcher, J., Gilbert, D., Fyall, A. \& Wanhill, S. (2004). Tourism principles and practice ( $3 r d$ ed). Financial Times Prentice Hall Publisher.

Er, A. C. (2013). Pembangunan pelancongan lestari di Malacca: Perspektif pelancong. Geografia Malaysian Journal of Society and Space 9(3), 12-23. http://journalarticle.ukm.my/6507/1/2.geografia-july_2013-er_ah_choy-edkat.pdf.

Chandra, F. A. (2014). Analysis of sustainable tourism livelihoods in Batu (East Java Indonesia): SLFT Approach (Sustainable livelihood framework for tourism). Journal of Economics and Sustainable Development 5(10), 148-156.

https://www.iiste.org/Journals/index.php/JEDS/article/view/13141.

Godfrey, K., \& Clarke, J. (2000). The Tourism Development Handbook: A Practical Approach to Planning and Marketing (1st ed). Cengage Learning Australia Limited Publisher.

Greenhill homestay. (2019). Greenhill homestay. Retrieved July 13, 2019 from http://www.greenhillhomestay.wordpress.com/tag/peta-ke-kundasang/.

Habibah, A., Hamzah, J., Chamhuri, S., Amriah, B., Shukri, M. H.N ., Shahrudin, M. I., \& Akma, Z. (2011). Pelancongan budaya di Koridor Ekonomi Wilayah Pantai Timur (ECER): Isu dan cabaran. Geografia Malaysian Journal of Society and Space 7, 180-189. http://journalarticle.ukm.my/3212/1/15.geografia-2011-4-sp-HABIBAHdkk-2.pdf.

Habibullah, M. S. (1999). Divisia Monetary Aggregates and Economic Activities in Asian Developing Economies (1st ed). Routledge Taylor \& Francis Group.

Hamid, A., \& Mohammad, M. (2015). The Impact of Sanctions on Destination Image Tourism of Iran. An international Multidisciplinary Journal of Tourism 10, 255-266. https://www.academia.edu/54657145/The_Impact_of_Sanctions_on_Destination_Im age_Tourism_of_Iran.

Hanizah, I., Norhaslin, H., Safiah @ Yusmah, M. Y., Asra, Z. A., \& Muhammad, F. R. (2017). Pembangunan Mampan Pelancongan Maritim di Pantai Timur Semenanjung Malaysia (1st ed). Universiti Malaya Press.

Hausman, D. M. (2001). Ecotourism. International Encylopedia of the Social \& Behavioral Sciences 9: 4165-4167.

Inskeep, E. (1991). Tourism planning: an integrated and sustainable development approach. Van Nostrand Reinhold.

https://journals.sagepub.com/doi/abs/10.1177/004728759303100459.

Jamaluddin, M. J. (2009). Pembangunan pelancongan dan impaknya terhadap persekitaran fizikal pinggir pantai. Malaysian Journal of Environmental Management 10(2), 71-87. http://journalarticle.ukm.my/2289/.

Joseph, E. M. (2003). The sosioeconomic and environmental impacts of tourism development on The Okavango Delta, North-Western Bostwana. Journal of Arid Environments, 54, 447-467. https://doi.org/10.1006/jare.2002.1101. 
Johan, A. I., Norhanim, A. R., \& Mohamad, Z. A. (2012). Impak Pembangunan Pelancongan Terhadap Destinasi Pantai Kajian Kes: Pantai Cenang, Langkawi. Prosiding PERKEM VII, Jilid 1, 601-610.

https://www.academia.edu/35523052/Impak_Pembangunan_Pelancongan_Terhadap _Destinasi_Pantai_Kajian_Kes_Pantai_Cenang_Langkawi.

Jurowski, C., Uysal, M., \& Williams, R. D. (1997). A theoretical analysis of host community resident reactions to tourism. Journal of Travel Research 36 (2), 3-11.

https://doi.org/10.1177/04728759703600202.

Ko, D. W., \& Stewart, W. P. (2002). A structural equation model of residents' attitudes for tourism development. Tourism Management 23, 521-530. https://dx.doi.org/10.1016/S0261-5177(02)00006-7.

Kuvan, Y., \& Akan, P. (2005). Residents' attitudes toward general and forest-related impacts of tourism: the case of Belek, Antalya. Tourism Management 26(5), 691-706. https://doi.org/10.1016/j.tourman.2004.02.019.

Loon, L. M. (2018). Sustainability of the Cultural Tourism in Sabah. TEAM Journal of Hospitality and Tourism 14(1), 29-42. https://teamjournalht.files.wordpress.com/2019/04/teamjournal_151_2018-article-3.pdf.

Milman, A., \& Pizam, A. (1988). Social impacts of tourism on central Florida. Annal's of Tourism Research 15, 191-204. https://doi.org/10.1016/0160-7383(88)90082-5.

Melanie, K. S. (2015). Issues in Cultural Tourism Studies (3rd ed). Routledge Taylor \& Francis Group.

Mondal, S., \& Sen, J. (2017, March 24-25). A framework of predictive analysis of tourist inflow in the beaches of West Bengal: A study of Digha-Mandarmoni Beach, India. In Proceeding of the First International Conference on Computational Intelligence, Communication and Business Analytics (CICBA-17), Kolkata, India. https://ssrn.com/abstract=2934372.

Mohamad, S. S., Ahmad, S., Sridar, R., \& Syamsul, H. M. A. (2013). Visitors' Satisfaction towards Service and Facilities in KILIM KARST Geoforest Park, Langkawi. Journal of Applied Economics and Business, 1(4), 25-42. http://www.aebjournal.org/articles/0104/010403.pdf.

Mohamad, Z. A., Johan, A. I., \& Hood, M. S. (2008). Membangunkan Kuala Kedah sebagai destinasi pelancongan warisan: Penerapan konsep pembangunan pelancongan lestari. Prosiding PERKEM III, Jilid 1, 401- 413. http://repo.uum.edu.my/id/eprint/7125.

Mohamed, A. O. D. (2008). Pelancongan-budaya: konsep dan profil di Malaysia. Jurnal Melayu 3 (3), 1-16. http://journalarticle.ukm.my/2999/.

Mohamed, A. O. D., \& Zulayti, Z. (2011). Pelancongan budaya di Malaysia: membina konsepnya. Jurnal Melayu, 6, 1-11. http://journalarticle.ukm.my/2900/1/1.pdf.

Mohd, S., \& Sulong, M. (2013). Pengaruh warisan sejarah dalam industri pelancongan Langkawi. International Journal of the Malay World and Civilisation, 1(1), 99-109. https://www.ukm.my/jatma/wp-content/uploads/makalah/IMAN1_9.pdf .

Mohd, U. M. (2018). Pelancongan sumbang 14.9 peratus ekonomi negara. Berita Harian. http://www.bharian.com.my/bisnes/lain-lain/2018/09/473549/pelancongansumbang-149-percentage-ekonomi-negara.

Moscardo, G. (1996). Mindful visitors: Heritage and tourism. Annals of Tourism Research, 23 (2), 376-397. https://doi.org/10.1016/0160-7383(95)00068-2. 
Muhammad, A. S. A. H., Aziz, A., \& Mohd, S. M. (2016). An affecting of community-based tourism toward integrated sustainable homestay in Malaysia. International Journal of Business and Management Study, 3(3), 17-21. https://www.academia.edu/34698697/An_Affecting_of_Community_Based_Tourism_ Toward_Integrated_Sustainable_Homestay_in_Malaysia.

Neumayer, E. (2004). The impact of political violence on tourism: dynamic cross - national estimation. The Journal of Conflict Resolution 48(2), 259-281. http://doi.org/10.1177\%2F0022002703262358.

Norlida, H. M. S., Hajar, S. M. I., Shafiin, M. S., \& Redzuan, O. (2013). Rangsangan motivasi ketibaan pelancong asing mengikut kawasan ke Malaysia. Sains Humanika, 64(1). https://doi.org/10.11113/sh.v64n1.6 .

Ramzah, D., \& Amriah, B. (2008). Memahami permasalahan pelancongan di Kundasang, Sabah: kekuatan dan kelemahan pendekatan positivism. Geografia Malaysian Journal of Society and Space 4, 20-31.

http://journalarticle.ukm.my/1604/1/Georafia_4\%2C1_\%2820-31\%29.pdf.

Ramkissoon, H. (2015). Authenticity, satisfaction, and place attachment: A conceptual framework for cultural tourism in African island economies. Development Southern Africa, 32 (3), 292-302.

Ritchie, J. R. B., \& Crouch, G. I. (2003). The competitive (micro) environment: The destination and the tourism system. In. Ritchie, J.R.B \& Crouch, G.I., The Competitive Destination: A Sustainable Tourism Perspective. CABI International. https://doi.org/10.1079/9780851996646.0000.

Rosmalina, A. R. (2012). Evaluation of Tourist's Image Preferences and Intention to Re-Visit Sabah. [Unpublished Doctoral Thesis]. Universiti Teknologi Malaysia.

Rosniza, A. C. R., Ahmad, M. M., Abdul, R. M. N., Rosmiza, M. Z., Novel, L., \& Mohd, A. A. (2012). Persepsi pelancong terhadap agensi pelancongan di Langkawi Geopark. Geografia-Malaysia Journal of Society and Space, 8 (7), 147-154. http://journalarticle.ukm.my/5659/.

Ross, G. F. (1992). Resident Perceptions of the impact of tourism on an Australian City. Journal of Travel Research, 30(13), 13-17. https://doi.org/10.1177\%2F004728759203000302.

Rummel, R. J. (1970). Applied Factor Analysis. Evanston, IL: Northwestern University Press. http://garfield.library.upenn.edu/classics1987/A1987H560200001.pdf.

Seetanah, B. (2010). Assessing The Dynamic Economic Impact of Tourism For Island Economies. Analysis of Tourism Management, 38, 291-381. https://doi.org/10.1016/j.annals.2010.08.009.

Scoones, I. (1998). Sustainable rural livelihoods: A framework for analysis. Brighton: University of Sussex, Institute of Development Studies.

https://www.ids.ac.uk/publications/sustainable-rural-livelihoods-a-framework-foranalysis/.

Salina, S. M., \& Zuliskandar, R. (2018). Potensi pembangunan pelancongan berasaskan warisan di Bandar Hilir, Malacca: Analisis SWOT. Asian Journal of Environment History and Heritage, 2(1), 253-265. https://spaj.ukm.my/ajehh/index.php/ajehh/article/view/55.

Norsakira, S. M., \& Aznie, R. C. R. (2018). Potensi bandar Kuala Lipis sebagai destinasi pelancongan warisan. Geografia Malaysian Journal of Society and Space 14 (1), 102115. http://journalarticle.ukm.my/12588/1/23454-69427-1-PB.pdf. 
Suhaya, S., Md, S. S., \& Norlida, H. M. S. (2013). Impak Pembangunan Industri Perlancongan Kepada Komuniti di Pulau Langkawi. Prosiding PERKEM VIII, Jilid 1, 207-216. https://www.ukm.my/fep/perkem/pdf/perkemVIII/PKEM2013_1D5.pdf.

Siow, M. L., Sridar, R., Ahmad, S., \& Syamsul, H. M. A. (2014). Barriers to community participation in rural tourism: A case study of the communities of Semporna, Sabah. Life Science Journal, 11(11), 837-841. http://psasir.upm.edu.my/id/eprint/36620/

Shukor, M. S., Salleh, N. H. M., Othman, R., \& Idris, S. H. M. (2014). Perception of homestay operators towards homestay development in Malaysia. Jurnal Pengurusan 42, 3-17. https://ejournal.ukm.my/pengurusan/article/view/9206.

Thiele, M. T., Pollnac, R. B., \& Christie, P. (2005). Relationship between coastal tourism and ICM sustainability in The Central Visayas Region of the Philippines. Ocean \& Coastal Management 48, 378-392. https://doi.org/10.1016/j.ocecoaman.2005.04.011.

UNESCO. (2019). Kinabalu park. Retrieved 2 May, 2019 from http://whc.unesco.org/en/list/1012.

Valene, L. S. (1979). Hosts and Guests: The Anthropology of Tourism. Philadelphia: University of Pennsylvania Press. https://www.jstor.org/stable/j.ctt3fhc8w.

Volare, A. W., \& Rimadewi. S. (2012). Pelestarian Kawasan Cagar Budaya Berbasis Partisipasi Masyarakat (Studi Kasus: Kawasan Cagar Budaya Bubutan, Surabaya). Jurnal Teknik Institut Teknologi Sepuluh, 1(1), 1-5.

http://dx.doi.org/10.12962/j23373539.v1i1.1026.

Wan, S. W. I., Rosilawati, Z., Siti Nor, A., Kamal, S. F., \& Juli, E. (2015). Pelancongan dan pembangunan setempat di Malaysia: Satu analisis SWOT Royal Belum sebagai produk ekopelancongan. Geografia Malaysian Journal of Society and Space, 11 (13), 115- 130. http://journalarticle.ukm.my/9778/. 